Syntax Literate : Jurnal Ilmiah Indonesia p-ISSN: 2541-0849

e-ISSN : 2548-1398

Vol. 5, No. 1 Januari 2020

\title{
ANALISIS AL-BAGHYU DALAM FIQIH JINAYAH TERHADAP MAKNA MAKAR DALAM PASAL 107 KUHP
}

\section{Putri Amalia Zubaedah dan Saeful Anwar}

Universitas Islam Negeri Bandung dan CV. Syntax Corporation Indonesia

Email: putt.mafazha@gmail.com danghopul93@gmail.com

\begin{abstract}
Abstrak
Makar merupakan perbuatan kejahatan yang mengancam keamanan Negara. Makar dalam hal menggulingkan pemerintahan dalam KUHP diatur pada pasal 107 bab II.Sedangkan dalam fiqh jinayah makar termasuk dalam jarimah albaghyu,Dengan latar belakang masalah tersebut diajukan tiga rumusan masalah, yakni: bagaimana substansi makar dalam pasal 107 KUHP, bagaimana penafsiran jarimah al- baghyu dalam fiqih jinayah, bagaimana relevansi makar dalam pasal 107 KUHP dengan jarimah al-baghyu dalam fiqih jinayah. Tujuan penelitian ini adalah untuk mengetahui substansi makar dalam pasal 107, Untuk mengetahui penafsiran jarimah al-baghyu dalam fiqih jinayah. Penelitian ini menggunakan pendekatan penelitian yuridis normatif. Jenis data yang dipergunakan dalam penulisan penelitian ini adalah jenis data kualitatif. Adapun sumber data yang digunakan adalah sumber data primer dari kitab tasyri al-jina'I karangan Abdul Qadir Audah dan KUHP karangan Moeljatno, dan data sekunder yaitu buku-buku fiqh jinayah dan buku-buku yang berhubungan dengan makar. Teknik pengumpulan data yang digunakan adaalah dengan cara library research. Analisis data yang digunakan yaitu analisis deskriptif kulitatif. Substansi makar dalam pasal 107 KUHP adalah perbuatan terencana yang bermaksud untuk menggulingkan pemerintahan yang sah dan mengancam keamanan dan keselamatan Negara. Dianalisis berdasarkan teori Jarimah Al-baghyu, makna makar dalam pasal 107 KUHP masuk pada pengertian perlawanan terhadap penguasa (imam) yang sah dengan menggunakan kekuatan atau mengangkat senjata. Relevansi antara Jarimah Al-baghyu dengan makna makar dalam pasal 107 KUHP adalah relevansi substantif, yaitu terdapat kemiripan makna dalam kriteria kejahatan.
\end{abstract}

Kata kunci: Fiqih jinayah, Makar, Al-Baghyu

\section{Pendahuluan}

Secara sederhana hukum dibedakan menjadi dua yaitu hukum positif (Hukum Indonesia) dan hukum agama (dalam hal ini Hukum Islam) (Mariana, 2018). Negara Indonesia ialah negara yang berpedoman akan hukum (rechtsstaat) serta bukan negara akan kekuasaan (machtsstaat), oleh karena itu kondisi hukum mesti diposisikan di atas segala-galanya. Setiap tindakan mesti sama dengan aturan hukum tanpa kecuali (Audah, n.d.). Berdasarkan Undang-Undang Nomor. 10 Tahun 2014 tentang Pembentukan Peraturan Perundang-Undangan di Indonesia, hirarki perundangan di Indonesia adalah 
Undang-undang Dasar Republik Indonesia Tahun 1945, Undang-Undang, Peraturan Pemerintah Pengganti Undang-undang, Peraturan Pemerintah, Peraturan Presiden, Peraturan Daerah, serta Peraturan lainnya. Berlandaskan hirarki tertib hukum tersebut, hingga pengaturan mengenai makar diatur dalam Undang-undang Republik Indonesia Nomor 1 Tahun 1946 Tentang KUHP.

Makar dilihat dari Kamus Besar Bahasa Indonesia adalah akal buruk, tipu muslihat atau perbuatan dengan maksud hendak membunuh orang.(Al-Maraghi, 1993) Sedangkan dalam Kamus Hukum Andi Hamzah, makar adalah Akal busuk; tipu muslihat; Perbuatan (usaha) dengan maksud hendak menyerang (membunuh) orang. Perbuatan (usaha) menjatuhkan pemerintah yang sah.(Al-Qurtubi, n.d.) Makar juga bisa diartikan sebagai perbuatan untuk menggulingkan pemerintahan yang sah (kudeta)(Andi Hamzah, n.d.-a). Istilah makar atau aanslag dalam bahasa Belanda, menurut R. Soesilo adalah penyerangan, yang umumnya dilaksanakan dengan perbuatan kekerasan.(Andi Hamzah, n.d.-b) Istilah makar dalam KUHP sendiri diawali penafsiran secara khusus yang bisa diawali dalam Pasal 87, yang berbunyi: Makar (aanslag) sesuatu perbuatan dianggap ada, apabila niat spembuat kejahatan sudah ternyata dengan dimulainya melakukan perbuatan itu menurut maksud pasal 53.

Kejahatan tindak pidana makar dalam KUHP Secara terminologis terdapat dalam Pasal 87 KUHP dimana perbuatan makar meliputi dua unsur yaitu niat dan adanya permulaan pelaksanaan niat makar. Dalam ketentuan pasal 87 KUHP disebutkan bahwa "makar" nyata-nyata suatu perbuatan dianggap ada apabila niat sipembuat kejahatan sudah melaksanakan perbuatan itu menurut maksud pasal 53 KUHP. Jadi yang termasuk dalam pengertian makar (aanslag) pada perbuatan pelaksanaan, bukan pada perbuatan persiapan (Kamus Besar Bahasa Indonesia, n.d.).

Dalam hal ini, Kitab Undang-Undang Hukum Pidana (KUHP) sendiri mengenal beberapa faktor yang menyebabkan atau memungkinkan kejahatan makar. Salah satunya adalah pasal 107 buku kedua bab II KUHP yang berbunyi :

1. Makar dengan arti agar menjatuhkan pemerintah, diancam dengan pidana penjara paling lama lima belas tahun.

2. Para pemimpin serta pengatur makar tersebut dalam ayat 1 , diancam dengan pidana penjara seumur hidup atau pidana penjara sementara paling lama dua puluh tahun (Jauhari, 2010).

Al-baghyu secara harfiah berarti meningggalkan atau melanggar.(Ibn Jarir atTabari, Jami' al-Bayan fi Ta'wil al-Quran, 2000) Dalam istilah hukum pidana Islam, Al-baghyu adalah suatu usaha atau gerakan yang dilakukan oleh suatu kelompok dengan tujuan menggulingkan pemerintahan yang sah (Asshiddiqie, 2006). Al-Baghyu berasal dari akar kata bagha yang secara arti kata berarti "menuntut sesuatu".

Jarimah al-baghyu termasuk kedalam kategori hudud. Kejahatan dalam kategori ini dikelompokan sebagai kejahatan yang diancam dengan hukuman had yakni hukuman yang ditentukan kadarnya sebagai hak Allah. Untuk bisa menemukan relevansi makar dengan jarimah Al-baghyu, oleh karena kita mesti paham secara 
terperinci terhadap apa yang dimaksud dengan makar atas hukum positif yaitu KUHP, khususnya dalam pasal 107. Sebagai pertimbangan, penulis juga akan mencoba paham secara terperinci pula terhadap apa yang disebut al-baghyu dalam fiqh jinayah. Sesudah itu kita akan bisa melihat apakah tindak pidana makar dalam KUHP itu bersangkutan dengan jarimah Al-baghyu dalam fiqh jinayah.

\section{Metode Penelitian}

Metode yang dipakai dalam penulisan ini ialah metode deskriptif analitis dalam bentuk content analisis pasal yakni pasal 107 KUHP. Metode penelitian ini memberikan tampilan atau uraian atas suatu keadaan sejelas mungkin tanpa ada perlakuan terhadap objek yang diteliti (M Sudrajat Bassar, 1984). Penelitian ini menggunakan pendekatan penelitian yuridis normatif yakni penelitian hukum kepustakaan adalah metode atau cara yang digunakan di dalam penelitian hukum yang dilakukan dengan cara meneliti bahan pustaka yang ada.(P.A.F.Lamintang dan Theo Lamintang, 2010) mengenai Analisis Al-Baghyu Dalam Fiqh Jinayah Terhadap Makna Makar Dalam Pasal 107 KUHP. Pendekatan yuridis-normatif ini dipergunakan karena penelitian yang peneliti lakukan dengan cara meneliti bahan pustaka yang merupakan data sekunder yang ditunjang oleh data primer (Pipin Syarifin, 2000).

Data tersebut diperoleh dari hasil studi literatur atau kepustakaan tentang objek yang sesuai dengan rumusan masalah. Yakni yang berhubungan dengan:

a. Substansi makar pada pasal 107 KUHP

b. Penafsiran Jarimah al-baghyu pada fiqih jinayah

c. Relevansi makar dalam pasal 107 KUHP dengan Jarimah al-baghyu dalam fiqih jinayah

Analisis data yang digunakan dalam penelitian ini adalah deskriptif kulitatif yaitu analisis yang dilakukan dengan jalan bekerja dengan data yakni mengumpulkan data, mengorganisasikan data, memilah-milahnya menjadi satuan yang dapat dikelola, mengelola data untuk diambil data yang dibutuhkan, menganalisis data yang telah dikumpulkan dihubungkan dengan pertanyaan penelitian yang diajukan dalam rumusan masalah kemudian menarik kesimpulan.

\section{Hasil dan Pembahasan}

\section{A. Substansi Makar Dalam Pasal 107 KUHP Tentang Tindak Pidana Kejahatan Terhadap Keamanan Negara}

Tindak pidana makar yang dilakukan dengan maksud untuk menggulingkan pemerintahan itu oleh pembentuk undang-undang telah diatur dalam pasal 107 KUHP, yang rumusannya dalam bahasa Belanda berbunyi sebagai berikut:

1) de aanslag ondernomen met het oogmerk om omwenteling teweg te brengen, wordt gestraft met gevangenisstraf van ten hoogste vijftien Jaren.

2) leiders en aanleggers van een aanslag als in het eerste lid bedoeld, worden gestraft met levenslange gevangenisstraf of tijdelijke van ten hoogste twintig 
Jaren.

Artinya :

1) Makar yang dilakukan dengan maksud menggulingkan pemerintah, dipidana dengan pidana penjara selama-lamanya lima belas tahun.

2) Pemimpin-pemimpin dan perencana-perencana makar seperti yang dimaksudkan dalam ayat (1) dipidana dengan pidana penjara seumur hidup atau dengan pidana penjara sementara selama-lamanya dua puluh tahun.

Dari rumusan tindak pidana yang diatur dalam pasal 107 KUHP diatas, kita dapat mengetahui bahwa tindak pidana makar yang dilakukan dengan maksud untuk menggulingkan pemerintah seperti yang diatur dalam pasal 107 KUHP mempunyai unsur-unsur sebagai berikut:

a. Unsur subjektif : met het oogmerk atau dengan maksud

b. Unsur objektif : 1. aanslag atau makar. ondernomen atau yang dilakukan omwenteling teweeg brengen atau menggulingkan pemerintah.

Tentang tiga buah unsur yang disebutkan pertama diatas, masing-masing unsur dengan maksud (met het oogmerk), unsur makar (aanslag), dan unsur yang dilakukan (ondernemen) kiranya sudah cukup jelas, sehingga tidak akan penulis bicarakan kembali. Dengan demikian yang belum dibicarakan hingga kini hanyalah unsur omwenteling teweeg brengen atau menggulingkan pemerintah.

Apa yang sebenarnya dimaksudkan dengan kata omwenteling teweeg brengen itu? Kata teweeg brengen itu sendiri mempunyai arti yang sama dengan veroorzaken atau menyebabkan ataupun menimbulkan. Mengenai kata omwenteling dalam rumusan pasal 107 KUHP diatas, dalam pasal 88 bis KUHP pembentuk undang-undang telah mmberikan penjelasannya sebagai berikut:

"yang dimaksudkan dengan menggulingkan pemerintah ialah menghancurkan atau mengubah bentuk pemerintah menurut undangundang dasar dengan cara yang tidak sah menurut undang-undang tata cara penggantian tahta atau tata cara dalam bentuk pemerintahan Indonesia yang sah menurut undang-undang."

Jika ketentuan pidana yang diatur dalam pasal 107 KUHP kita hubungkan dengan penafsiran autentik dari pembentuk undang-undang mengenai kata omwenteling dalam pasal 88 bis KUHP diatas, akan dapat diketahui bahwa yang dilarang dalam pasal 107 KUHP ayat (1) sebenarnya ialah perbuatan makar yang dilakukan dengan maksud untuk menyebabkan :

a. Menghancurkan bentuk pemerintahan menurut undang-undang dasar.

b. Mengubah secara tidak sah bentuk pemerintahan menurut undang undang dasar.

Dalam hal ini kiranya perlu dijelaskan terlebih dahulu tentang apa yang sebenarnya dimaksudkan dengan kata regeringsvorm dalam rumusan pasal 107 ayat (1) KUHP, karena didalam kepustakaan ternyata ada perbedaan pendapat mengenai arti dari regeringsvorm atau bentuk pemerintahan dengan arti dari staatsvorm atau bentuk Negara. 
Tentang staatsvorm atau bentuk Negara, Negara Indonesia itu diatur dalam Bab I Pasal I Undang-undang Dasar Republik Indonesia 1945, yang menetukan:

1) Negara Indonesia ialah Negara kesatuan, yang berbentuk republik.

2) Kedaulatan adalah ditangan rakyat dan dilaksanakan menurut undangundang dasar.

3) Negara Indonesia ialah Negara hukum.

Dari ketentuan yang diatur dalam Pasal 1 ayat (1) dan ayat (2) Undangundang Dasar Republik Indonesia 1945 tersebut dapat diketahui bahwa bentuk Negara indonesia itu ialah suatu Negara kesatuan yang berbentuk republik dan yang sifatnya demokratis.

Tentang kata demokrasi itu sendiri, Prof. Dr. P. van Woestijne menjelaskan: Secara harfiah ia berarti kedaulatan ada ditangan rakyat. Dalam politik ia juga digunakan untuk menunjukkan bentuk Negara, dalam Negara mana kekuasaan tertinggi berada ditangan rakyat. Pada zaman dahulu rakyat itu menyelenggarakan sendiri kekuasaan yang ia miliki melalui suatu pertemuan rakyat. Pada zaman modern ini sistem perwakilan itu sudah umum dipakai orang diberbagai Negara, dimana kekuasaan yang berada ditangan rakyat itu diselenggarakan oleh dewan perwakilan rakyat yang anggota-anggotanya dipilih oleh rakyat.

Menurut Lamintang dan Theo Lamintang, perbuatan-perbuatan mengubah bentuk Negara atau staatsvorm seperti yang dimaksudkan diatas bukan merupakan tindak pidana seperti yang dimaksudkan oleh pembentuk undang-undang dalam rumusan pasal 107 ayat (1) KUHP karena menurut penjelasan dalam pasal 88 bis KUHP, pembentuk undang-undang dengan jelas telah tidak berbicara tentang bentuk Negara atau staatsvorm melainkan hanya berbicara tentang regeringsvormn atau bentuk pemerintahan Indonesia yang sah menurut undang-undang dasar.

Sedangkan Wirdjono Prodjodikoro mengartikan kata regeringsvormn atau bentuk pemerintahan dalam pasal 88 bis sama halnya dengan kata staatsvorm atau bentuk Negara. Sehingga perbuatan-perbuatan mengubah bentuk Negara atau staatsvorm seperti diatas merupakan tindak pidana seperti yang dimaksudkan oleh pembentuk undang-undang dalam rumusan pasal 107 ayat (1) KUHP.

Menurut Lamintang dan Theo Lamintang, tindakan Wirdjono dalam memperluaskan arti makna staatsvorm dengan regeringsvormn ini merupakan suatu extensieve interpretative yang terlarang untuk digunakan dalam hukum pidana.

Namun jika merujuk pada pendapat Lamintang dan Theo Lamintang yang mengatakan bahwa mengubah staatsvorm atau bentuk Negara bukanlah suatu tindak pidana dan tidak dapat dipidana, maka hal ini akan bertentangan dengan pasal 37 ayat (5) UUD 1945 yang mengatakan bahwa bentuk Negara tidak dapat diubah. Oleh karena itu penulis lebih merujuk pada pendapat Wirdjono Prodjodikoro yang mengartikan kata regeringsvormn atau bentuk pemerintahan dalam pasal 88 bis sama halnya dengan kata staatsvorm atau bentuk Negara. Sehingga perbuatan-perbuatan mengubah bentuk Negara atau staatsvorm seperti diatas merupakan tindak pidana seperti yang dimaksudkan oleh pembentuk undang- 
undang dalam rumusan pasal 107 ayat (1) KUHP.

Jadi, istilah menggulingkan Pemerintah (omwenteling), ini oleh pasal 88bis ditafsirkan sebagai :

a. Menghancurkan bentuk pemerintahan menurut undang-undang dasar.

b. Mengubah secara tidak sah bentuk pemerintahan menurut undang- undang dasar.

Dalam cara penggulingan pemerintahan jenis pertama yaitu menghancurkan bentuk pemerintahan menurut undang-undang dasar itu tentunya sudah dengan sendirinya dianggap selalu sah. Hal inilah yang membedakan dengan cara penggulingan pemerintahan jenis kedua dimana redaksi kata-katanya sebagai berikut; "mengubah secara tidak sah" sehingga tentunya dimungkinkan adanya bentuk pemerintahan secara sah yang tentunya tidak termasuk penggulingan pemerintahan, misalnya dengan cara yang ditentukan dalam undang-undang dasar.

Dalam hal menghancurkan bentuk pemerintahan menurut undang-undang dasar itu Wirdjono Prodjodikoro memberi contoh misalnya bentuk republik menjadi kerajaan atau konkritnya misalnya menghapuskan sama sekali undangundang dasar dan menggantinya dengan undang-undang dasar baru.

Dalam hal mengubah secara tidak sah bentuk pemerintahan menurut undang-undang dasar beliau memberi contoh misalnya menghilangkan adanya menteri-menteri atau kementian-kementrian dan digantikannya dengan pejabatpejabat semacam penasihat-penasihat dari kepala Negara, atau awalnya menghilangkan dewan pertimbangan agung atau badan pengawas keuangan. Dalam hal ini harus dilakukan secara tidak sah, yakni dengan cara-cara yang tidak sesuai dengan ketentuan undang-undang dasar. Adapun jika dilakukan sesuai dengan ketentuan undang-undang maka tidak dapat dipidana sebagai makar pasal 107 Adapun cara yang sah untuk mengubah bentuk pemerintahan tersebut telah diatur dalam undang-undang dasar 1945 pasal 37 ayat (1) - (4) yang berbunyi :

Pasal 37

1. Usul perubahan pasal-pasal Undang-Undang Dasar dapat diagendakan dalam sidang Majelis Permusyawaratan Rakyat apabila diajukan oleh sekurang kurangnya 1/3 dari jumlah anggota Majelis Permusyawaratan Rakyat.

2. Setiap usul perubahan pasal-pasal Undang-Undang Dasar diajukan secara tertulis dan ditunjukkan dengan jelas bagian yang diusulkan untuk diubah beserta alasannya.

3. Untuk mengubah pasal-pasal Undang-Undang Dasar, Sidang Majelis Permusyawaratan Rakyat dihadiri oleh sekurang-kurangnya 2/3 dari jumlah anggota Majelis Permusyawaratan Rakyat.

4. Putusan untuk mengubah pasal-pasal Undang-Undang Dasar dilakukan dengan persetujuan sekurang-kurangnya lima puluh persen ditambah satu anggota dari seluruh anggota Majelis Permusyawaratan Rakyat.

5. Khusus mengenai bentuk Negara Kesatuan Republik Indonesia tidak dapat dilakukan perubahan. 
Rumusan pasal 107 KUHP bahwa makar dengan maksud menggulingkan pemerintahan tidaklah harus dilakukan dengan kekerasan (bersenjata), namun cukup dengan segala perbuatan yang tidak sesuai dengan peraturan perundangundangan yang berlaku. Digunakannya kata omwenteling yang diterjemahkan dengan kata menggulingkan pemerintahan itu memang dapat menimbulkan kesalahpahaman seolah-olah makar itu merupakan suatu tindak kekerasan untuk menggulingkan pemerintahan, padahal tindakan seseorang itu telah dapat dipandang sebagai suatu makar dengan maksud menggulingkan pemerintahan yakni jika tindakan orang tersebut telah melampaui batas-batas dari suatu tindakan persiapan dengan melakukan tindakan yang telah dapat dipandang sebagai suatu permulaan pelaksanaan dari maksudnya untuk menggulingkan pemerintahan (Asshiddiqie, 2006).

\section{B. Penafsiran Jarimah Al-Baghyu dalam Fiqih Jinayah}

Berdasarkan pembagian jarimah dalam fiqih jinayah, maka perbuatan albaghyu atau pemberontakan merupakan bagian dari jarimah hudud, karena jenis dan sanksinya sudah diatur secara tegas di dalam Al-Qur'an dan Hadits. Dasar hukum mengenai jarimah al-baghyu ini diatur dalam Al-Qur'an surat Al-Hujurat ayat 9:

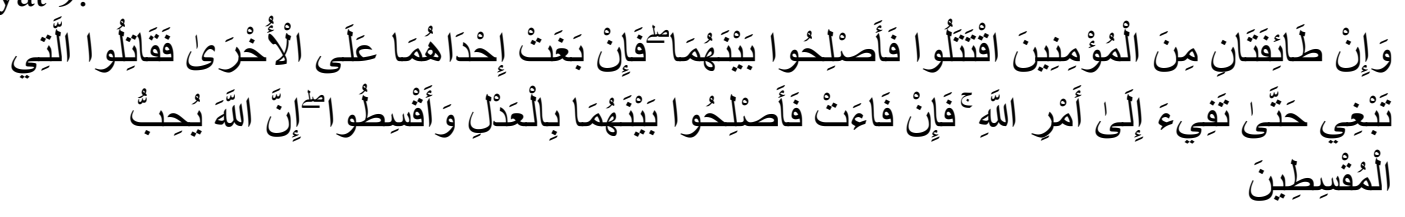

"Dan jika ada dua golongan dari orang-orang mukmin berperang, maka damaikanlah antara keduanya. Jika salah satu dari kedua golongan itu, berbuat aniaya terhadap golongan lain, maka perangilah golongan yang berbuat aniaya itu sehingga golongan itu kembali kepada perintah Allah, jika golongan itu telah kembali (kepada perintah Allah), maka damaikanlah antara keduanya dengan adil dan berlaku adillah. Sesungguhnya Allah menyukai orang-orang yang berlaku adil."

Menurut penulis, ayat ini berhubungan erat dengan jarimah al-baghyu (pemberontakan), terbukti dari kalimat yang terdapat dalam ayat tersebut yaitu "fain baghat". Menurut Ahmad Musthafa Al-Maraghi, baghat ialah menyerang dan berlaku aniaya. Beliau menafsirkan bahwa yang dimaksud menyerang dan berlaku aniaya (baghat) ialah apabila tidak mau menerima hukum Allah dan menerjang apa yang oleh Allah dijadikan sebagai keadilan diantara makhluk-Nya, sedang yang lain mau menerimanya.

Sedangkan menurut Ibnu Jarir at-Tabari mendefinisikan al-Baghyu dengan حده وتجاوز زىادته (menuntut lebih dan melampaui batasan). Adapun mengenai pandangan Ibn Jarir at-Tabari terhadap Surah Al-Hujurat ayat 9 ini adalah bahwa jika ada dua kelompok yang saling berperang hendaknya langkah paling awal dilakukan adalah dengan mendamaikan keduanya, dengan menyeru keduanya kepada hukum dari Kitabullah, dan kedua kelompok harusnya rela dengan 
ketetapan hukum yang ada pada Kitabullah tersebut. Ibnu Jarir berpandangan bahwa memerangi kelompok yang Bughat juga termasuk menghindari dari makar mereka sehingga tindakan memberantas, memerangi mereka dilakukan dalam rangka mencegah makar mereka terhadap yang lain. Ibnu Jarir mendasarkan pendapatnya tersebut berdasarkan riwayat-riwayat yang disuguhkan dalam tafsirnya terutama mengenai sebab diturunkannya surah al-Hujurat ayat 9. Secara umum Ibnu Jarir berpandangan baghat sebagaimana yang difahami oleh para fuqaha,

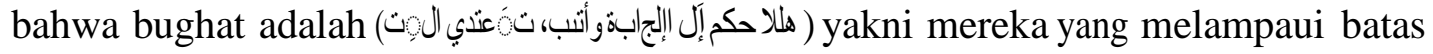
dan enggan untuk menerima apa yang ditetapkan dalam hukum Allah.

Sedangkan al-Qurtubi mendefinisikan kata baghat dengan (والفساد التطاول) yakni sikap sombong dan tindakan pengerusakan. Disisi lain al-Qurtubi juga mendefinisikannya sebagai tindak kedzaliman yang dilakukan seseorang kepada yang lainnya, melampaui batas, dan menuntut lebih dari haknya. Lebih luas lagi, menurut al-Qurtubi al-Bughat adalah melampaui batas, sombong dan meninggalkan kewajiban, atau rasa kesakitan yang terlalu ketika lapar dan haus. Lebih jauh, alQurtubi mengutip perkataan Ibn 'Abbas dalam mendefinisikan makna kalimat alBaghyu dalam ayat diatas dengan,

$$
\text { لو أعطاهم الكثير لطلبو اما هو أكثر منه ب غيهم طلبهم منزلة بعد منزلة لةوقيل أر اد }
$$

Artinya: "Tindakan al-Bagyu mereka maksudnya tuntunan mereka akan suatu kedudukan setelah mereka memiliki kedudukan (sebelumnya). Dan dikatakan, (maksudnya) keinginan yang jika diberikan kepada mereka sesuatu yang banyak, mereka menginginkan lagi yang lebih banyak dari itu."

Dari ketiga penafsiran yang dikemukakan oleh ahli tafsir diatas, dapat ditarik kesimpulan bahwa yang disebut jarimah al-baghyu adalah apabila :

\section{Menyerang dan berlaku aniaya}

Ialah apabila tidak mau menerima hukum Allah dan menerjang apa yang oleh Allah dijadikan sebagai keadilan diantara makhluk-Nya, sedang yang lain mau menerimanya.

2. Menuntut lebih dan melampaui batasan

Ialah mereka yang melampaui batas dan enggan untuk menerima apa yang ditetapkan dalam hukum Allah.

\section{Relevansi Makar Dalam Pasal 107 KUHP Dengan Jarimah Al-Baghyu Dalam Fiqih Jinayah}

Relevansi tindak pidana makar dalam pasal 107 KUHP dengan jarimah albaghyu dalam fiqih jinayah, akan terlihat dari unsur-unsur yang terkandung didalam tindak pidana makar yang terdapat dalam pasal 107 KUHP dengan unsur- unsur yang terkandung didalam jarimah al-baghyu dalam fiqih jinayah tersebut. Berikut unsur-unsurnya:

1. Unsur-unsur makar pada pasal 107 KUHP

Makar dengan maksud menggulingkan pemerintahan (menghancurkan atau mengubah secaratidak sah bentuk pemerintahan menurut undang-undang 
dasar).

2. Unsur-unsur jarimah al-baghyu

a. Pembangkangan terhadap kepala Negara melawan dengan kekuatan/senjata adanya niat melawan hukum.

Setelah dilihat unsur-unsur dalam pasal 107 KUHP tentang tindak pidana kejahatan terhadap keamanan Negara (makar) dengan unsur-unsur jarimah al- baghyu dalam fiqih jinayah maka terdapat perbedaan dalam hal unsur-unsurnya. Tindak pidana makar dalam pasal 107 KUHP tidak memiliki unsur "melawan dengan kekuatan/senjata" seperti yang dimiliki pada unsur jarimah al-baghyu. Tindak pidana makar dalam pasal 107 KUHP hanya memiliki unsur dengan maksud dan menggulingkan pemerintah, yang berarti pada pasal ini seseorang atau sekelompok orang sudah dapat dipidana apabila menggulingkan pemerintahan walaupun dengan tidak memakai kekuatan/senjata. Sedangkan pada jarimah albaghyu dalam fiqih jinayah, seseorang atau sekelompok orang baru bisa dipidana dan dikatakan al-baghyu apabila memakai kekuatan/senjata.

Rumusan pasal 107 KUHP tersebut dalam fiqih jinayah akan lebih sesuai jika dikatakan atau dimasukkan dalam kategori "pembangkang" saja bukan "pemberontak" atau al-baghyu karena tidak memiliki unsur "melawan dengan kekuatan/senjata"

Suatu perbuatan pembangkangan dinilai sebagai pemberontakan disyaratkan harus adanya penggunaan dan pengerahan kekuatan. Jika tidak diikuti dengan kekuatan hingga hal itu tidak dinilai sebagai pemberontakan seperti contoh penolakan sayyidina Ali untuk membaiat Abu bakar, pembangkangan (keluarnya) kelompok khawarij dari sayyidina Ali. Mereka tidak dinilai sebagai perbuatan pemberontakan karena tidak adanya kekuatan yang muncul dari pembangkangan tersebut, oleh sebab itu jika hanya sekedar ide dan sikap yang menggambarkankan pembangkangan maka hal tersebut belum bisa dikatakan pemberontakan.

Pemberontakan menurut imam malik, imam syafi'i, imam ahmad diawali semenjak dipakainya kekuatan secara nyata. Jika tidak memakai kekuatan maka pembangkangan itu belum dianggap sebagai pemberontakan, dan mereka diperlakukan sebagai orang yang adil (tidak bersalah) dan hanya dikatagorikan sebagai ta'zir. Pembangkang tidak dapat dikategorikan sebagai jarimah hudud karena ada unsur yang tidak terpenuhi. Maka dalam hal sanksi pun tidak dapat dikenakan sanksi hudud yakni diperangi melainkan hanya dapat dikenakan sanksi ta'zir yang mana hukumannya bisa lebih ringan, tergantung pertimbangan hakim.

Tidak dimasukkannya unsur "melawan dengan kekuatan/senjata" dalam rumusan pasal 107 KUHP barangkali merupakan upaya pembentuk 
undang-undang untuk lebih waspada dalam menjaga keamanan Negara, karena konsekuensi dari pasal 107 KUHP ini seseorang akan dapat dipidana dengan tuduhan makar apabila ia berusaha menggulingkan pemerintahan dengan cara yang tidak sah menurut undang-undang dasar walaupun tidak dengan menggunakan kekuatan/senjata.

\section{Kesimpulan}

Dari pembahasan tentang tinjauan hukum Islam terhadap tindak pidana makar dalam KUHP Pasal 107 di atas, dapat diambil beberapa kesimpulan:

1. Unsur-unsur tindak pidana makar Pasal 107 KUHP yang didalamnya ada dua unsur yaitu unsur subyektif serta unsur obyektif. Pasal 107 ada unsur subyektif: dengan maksud serta unsur obyektif: makar, yang dilaksanakan serta merobohkan pemerintah. Mengenai unsur-unsur tindak pidana makar diatas, penulis berpendapat bahwa unsur-unsur yang dari awal yang melekat pada diri si pelaku yang bertujuan untuk melakukan kejahatan pada keamanan Presiden dan Wakil Presiden, menyerang keamanan dan keutuhan wilayah negara.

2. Menurut hukum pidana islam, tindak pidana makar disebut dengan al-baghyu (pemberontakan). Di dalam hukum Islam tidak menjelaskan lebih rinci mengenai obyek tindak pidana pemberontakan (al-baghyu) contohnya kejahatan terhadap keamanan kepala negara, keamanan keutuhan wilayah negara dan keamanan bentuk pemerintahan. Dari segi perbedaan, dalam hukum islam pelaku diberikan sanksi apabila kejahatan dilakukan telah selesai dengan kata lain tindakan al-baghyu yang dilakukan telah sampai selesai dilakukannya. Sedangkan dalam hukum positif, pelaku makar sudah bisa diberikan sanksi baik kejahatan yang dilakukannya belum selesai atau telah selesai dilakukan. Sedangkan dalam hal persamaannya adalah baik pelaku al-baghyu maupun makar, keduanya bisa dijatuhi hukuman mati. 


\section{BIBLIOGRAFI}

Al-Maraghi, A. M. (1993). Terjemah Tafsir Al-Maraghi. Semarang: CV Toha Putra.

Al-Qurtubi, al-J. li A. al-Q. (n.d.). 1964),. Kairo: Dar al-Kutub.

Andi Hamzah. (n.d.-a). kamus hukum pidana. hlm 623.

Andi Hamzah. (n.d.-b). KUHP dan KUHAP. hlm 45.

Asshiddiqie, J. (2006). Konstitusi dan Konstitusionalisme Indonesia. Jakarta: Sekretariat Jenderal dan Kepaniteraan Mahkamah Konstitusi RI.

Audah, A. Q. (n.d.). Ensiklopedi Hukum Pidana Islam. Bogor: PT. Kharisma Ilmu.

Ibn Jarir at-Tabari, Jami' al-Bayan fi Ta'wil al-Quran. (2000). Beirut: Muasasah arRisalah,.

Jauhari, H. (2010). Panduan Penulisan Skripsi, Teori Dan Aplikasinya. Bandung: Pustaka Setia.

Kamus Besar Bahasa Indonesia. (n.d.). Departemen Pendidikan dan Kebudayaan. Jakarta: Balai Pustaka.

M Sudrajat Bassar. (1984). Tindak-tindak pidana tertentu dalam KUHP. Bandung: Remadja karya CV.

Mariana, M. (2018). Perlindungan Hukum Islam Terhadap Istri Yang Dituduh Melakukan Zina Oleh Suami. Syntax Literate; Jurnal Ilmiah Indonesia, 3(2), 7081.

P.A.F.Lamintang dan Theo Lamintang. (2010). Kejahatan Terhadap Kepentingan Hukum Negara. Jakarta: Sinar Grafika.

Pipin Syarifin. (2000). Hukum Pidaana di Indonesia, Cetakan ke-II. Bandung: CV Pustaka Setia. 